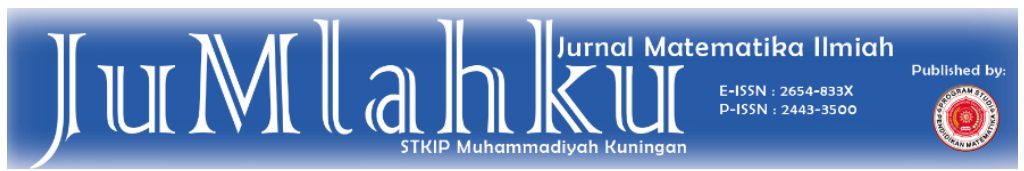

Submited: 2021-10-02

Published: 2021-11-28

\title{
Kemampuan Pemecahan Masalah Matematis Siswa Ditinjau dari Gaya Belajar teori Honey Mumford
}

\author{
Evi Susanti ${ }^{a}$, Nindy Citroresmi P. $^{\text {b) }}$ \\ a STKIP Singkawang (Pendidikan Matematika, STKIP Singkawang) \\ b STKIP Singkawang (Pendidikan Matematika, STKIP Singkawang)
}

Corresponding Author : evisusanti2806@gmail.com, nindy.citroresmi@gmail.com

\begin{tabular}{|c|c|}
\hline Article Info & Abstract \\
\hline $\begin{array}{l}\text { Keywords :, problem } \\
\text { solving ability, learning } \\
\text { style, honey mumford }\end{array}$ & $\begin{array}{l}\text { This study aims to describe the mathematical problem solving ability of } \\
\text { students at SMA Negeri } 6 \text { Singkawang in terms of learning styles } \\
\text { according to honey mumford on the material of the Three Variable } \\
\text { Linear Equation System. The type of research used in this research is } \\
\text { qualitative research using descriptive method. The subjects in this study } \\
\text { were students of class X SMA Negeri } 6 \text { Singkawang, totaling } 21 \text { people. } \\
\text { Data collection techniques used are questionnaire techniques, test } \\
\text { techniques and interview techniques. The instruments in this study } \\
\text { were Honey Mumford's learning style questionnaire, mathematical } \\
\text { problem solving ability test questions and interview guidelines. The data } \\
\text { analysis technique used in this research is data reduction, data } \\
\text { presentation and conclusion drawing. The results of this study indicate } \\
\text { that: 1) Students who have an active learning style have a tendency to } \\
\text { be happy with new experiences or problems, students with this type of } \\
\text { learning are able to understand problems, plan problems, carry out, but } \\
\text { are a little hasty in re-examining. 2) students with reflector learning } \\
\text { styles have high observation skills so that they help students solve } \\
\text { problems but do problems when under pressure. 3) students who have } \\
\text { a pragmatic learning style have a tendency to like practical ways of } \\
\text { learning, with this learning style they have difficulty planning balance. } \\
\text { 4) Students who have a theoretical learning style have good solving } \\
\text { abilities }\end{array}$ \\
\hline
\end{tabular}


Kata Kunci: kemampuan pemecahan masalah, gaya belajar, honey mumford.

\begin{abstract}
Penelitian ini bertujuan untuk mendeskripsikan kemampuan pemecahhan masalah matematis siswa di SMA Negeri 6 Singkawang ditinjau dari gaya belajar menurut honey mumford pada materi Sistem Persamaan Linear Tiga Variabel. Jenis peneltian yang digunakan dalam penelitian ini adalah penelitian kualitatif dengan menggunakan metode deskriptif. Subjek dalam penelitian ini adalah siswa kelas X SMA Negeri 6 Singkawang yang berjumlah 21 orang. Teknik pengumpulan data yag digunakan adalah teknik kuesioner, teknik tes dan teknik wawancara. Instrument dalam penelitian ini adalah angket gaya belajar Honey mumford, soal tes kemampuan pemecahan masalah matematis dan pedoman wawancara. Teknik analisis data yang digunakan dalam penelitian ini adalah reduksi data, penyajian data dan penarikan kesimpulan. Hasil penelitian ini menunjukkan bahwa: 1) Siswa yang memiliki gaya belajar aktivis memiliki kecendrungan senang dengan pengalaman atau permasalahan baru, siswa dengan tipe gaya belajar ini mampu memahami masalah, merencanakan masalah, merencanakan penyelesaian, melaksanakan penyelesaian namun sedikit tergesagesa dalam memerikasa kembali. 2) siswa degan gaya belajar reflektor memiliki kemampuan observasi yang tinggi sehingga membantu siswa dalam menyelesaikan masalah namun melakukan kesalahn jika di bawah tekanan. 3) siswa yang memiliki gaya belajar pragmatis memiliki kecendrungan menyukai cara-cara praktis dalam belajar, siswa dengan gaya belajar ini mengalami kesulitan saat merencanakan penyelesaian. 4) Siswa yang memiliki gaya belajar teoritis memiliki kemampuan pemecahan yang baik .
\end{abstract}

\section{PENDAHULUAN}

Dalam pembelajaran matematika, terdapat beberapa kemampuan yang harus dimiliki oleh siswa satu diantaranya adalah kemampuan pemecahan masalah matematis. Kemampuan pemecahan masalah merupakan kemampuan tingkat tinggi yang penting dan mendasar dalam kurikulum matematika, karena di dalam proses pembelajran maupun penyelesaian siswa memungkinkan untuk dapat memperoleh pengetahuan serta menggunakan pengetahuan yang sudah dimiliki untuk digunakan dalam pemecahan masalah ( Mariam dkk, 2019:179). Lebih lanjut Rosmawati (2012:81) mengatakan bahwa kemampuan pemecahan masalah matematis merupakan kemampuan penting karena dapat membantu siswa mengembangkan keterampilan dan intelektual dan mengajarkan bagaimana memecahkan masalah dengan menggunakan langkah-langkah pemecahan masalah.

Dahar (2011:121) menyatakan bahwa tujuan utama proses pendidikan yakni 
memecahkan masalah atau kemampuan siswa dalam memecahkan masalah. Siswa yang memiliki kemampuan pemecahan masalah mampu berpikir analitik dalam mengambil keputusan dalam kehidupan sehari-hari dan membantu meningkatkan kemampuan berpikir kritis dalam menghadapi situasi baru (Cooney dalam Sumarmo(2014)). Dengan demikian pentingnya kepemilikan kemampuan pemecahan masalah bagi siswa selaras dengan kebermaknaan belajar yang mana komponen yang sangat penting didalamnya adlah pemecahan masalah.

Dalam penelitian ini terdapat indicator pemecahan masalah menurut Polya (Palapasari \& Anggo, 2019: 47) terdapat tahap-tahap dalam memecahkan masalah yaitu ; (1) memahami soal atau masalah; (2) membuat rencana atau cara untuk menyelesaikannya; (3) menyelesaikan masalah; (4) memeriksa kembali hasil yang didapat.

Kemampuan pemecahan masalah di sekolah nyatanya belum diperhatikan dalam pembelajaran matematika disekolah. Hal ini diperoleh berdasarkan hasil observasi yag dilakukan di SMA Negeri 6 Singkawang pada bulan Mei 2021. Dari hasil observasi diketahui kemampuan pemecahan masalah siswa masih belum optimal. Pada saat siswa diberikan permasalahan dalam bentuk soal rutin siswa mampu meyelesaikan persoaln tersebut, tetapi jika permasalahan yang dibeikan merupakan suatu permasalahan yang non-rutin, siswa mengalami kesulitan dan kurang mampu menyelesaikannya. Siswa hanya mampu menyelesaikan permasalahan yang diberikan bila permasalahan tersebut adalah soal-soal dengan tipe yag sama dan menjadi bingung bila soal yang diberikan lebih bervariasi.

Satu diantara materi yang esensial dan sering dijumpai di kehidupan sehari-hari adalah Sistem Persamaan Linear Tiga Variabel. Soal-soal pada materi ini dapat diaplikasikan untuk menyelesaikan permasalahan dalam kehidupan sehari-hari, sehingga sangat layak digunakan untuk mengetahui kemampuan pemecahan masalah siswa.

Gaya belajar merupakan cara, karakteristik dan perilaku seseorang atau individu dalam menyerap, mengolah, memahami suatu informasi, data atau pelajaran (Heryani \& Ramadani, 2019: 67). Gaya belajar merupakan ciri khas perilaku setiap individu saat berada pada lingkungan belajar. Honey dan Mumford (Handoko \& Wrastari, 2014:92) mendefinisikan gaya belajar sebagai sebuah penjelsan mengenai sikap dan perilaku yang ditentukan dari belajar yang terbaik menurut masing-masing individu. Dalam memahami, mengolah dan menyampaikan data informasi atau pelajaran antara individu yang satu dengan yang lainnya memiliki cara tersendiri yang pastinya berbeda satu dengan yang lainnya. Gaya belajar menurut Honey Mumford ( Heryani, 2019: 67) dibagi menjadi 4 yaitu; aktivis yang lebih suka melibatkan dirinya pada pengalaman baru, reflector yang belajarnya dengan cara mengamati dan memikirkan konsekuensi yang akan terjadi, pragmatis yang cenderung tidak sabar dan terbuka dalam diskusi dan teoritis yang lebih suka mengerjakan sesuatu berdasarkan teori-teori sebelumnya. 
Penelitian ini mendeskripsikan bagaimana kemampuan pemecahan masalah matematis siswa berdasarkan gaya belajar Honey Mumford yaitu ; bagaimana kemampuan pemecahan masalah matematis siswa yang bergaya belajar aktivis, bagaimana kemampuan pemecahan masalah matematis siswa yang bergaya belajar reflector, bagaiman kemampuan pemecahan masalah matematis siswa yang bergaya belajar pragmatis, dan bagaimana kemampuan pemecahan masalah matematis sisiwa yang bergaya belajar teoritis.

Penelitian ini diharapkan dapat memberikan manfaat di dunia pendidikan terlebih khusus pada mata pelajaran matematika. Dapat menjadi bahan acuan peneliti selanjutnya yang akan meneliti topic yang sama yaitu tentang kemampuan pemecahan masalah yang ditinjau dari gaya belajar Honey Mumford.

\section{METODE}

Penelitian ini merupakan penelitian deskriptif dengan pendekatan kualitatif. Penelitian ini dilakukan di SMA Negeri 6 Singkawang pada semester genap. Subjek dalam penelitian ini adalah siswa kelas $X \mathrm{~A}$ yang berjumlah 21 orang dan dipilih delapan orang subjek penelitian yaitu dua orang siswa yang bergaya belajar aktivis, dua orang bergaya reflector, dua orang bergaya pragmatis dan dua orang bergaya teoritis. Subjek penelitian dipilih dengan teknik purposive sampling yaitu teknik pengambilan sampel dengan pertimbangan tertentu (Sugiyono, 2014: 302). Yaitu pertimbangan dari penyebaranangket gaya belajar Honey Mumford.

Teknik pengumpulan data yang dilakukan dengan memberikan angket gaya belajar Honey Mumford (Angkel LSQ (Learning Style Questionaire)) yang terdiri dari 80 pertanyaan mengenai empat gaya belajar. Yang dijawab dengan setuju dan tidak setuju, jawaban setuju diberi skor 1 dan tidak setuju diberi skor 0 . Pemberian angket ini untuk mengetahui gaya belajar siswa.

Selanjutnya adalah tes kemampuan pemecahan masalah yang berupa soal uraian mengenai materi Sistem Persamaan Linear Tiga Variabel sebanyak 2 soal dengan rentang pengerjaan selama 60 menit. Pemberian tes ini digunakan untuk mendapatkan informasi tentang kemampuan pemecahan masalah matematis siswa.

Selanjutnya adalah wawancara, yang menggunakan wawancara terstruktur yang dilakukan setelah pemberian tes kemampuan pemecahan masalah, dengan tujuan untuk menguji kredibilitas hasil tes kemampuan pemecahan masalah siswa.

Data yang diperoleh dianalisis dengan analisi data meurut Sugiyono (2015: 246) yaitu Data Reduction (Reduksi data), Data Display (Penyajian data), Conclusion drawing/Verification ( Penarikan 
Kesimpulan). Dan triangulasi yang digunakan adalah triangulasi teknik.

\section{HASIL DAN PEMBAHASAN}

Dari hasil pemberian angket gaya belajar honey Mumford ( Angket LSQ) kepada siswa kelas X A SMA Negeri 6 Singkawang, terpilih 8 orang siswa yang dijadikan subjek, 2 orang bergaya belajar aktivis, 2 orang bergaya belajar reflector, 2 orang bergaya belajar pragmatis dan 2 orang bergaya teoritis. Kedelapan subjek tersebut diberi kode $A 1$ dan $A 2$ untuk subjek dengan gaya belajar aktivis, B1 dan B2 untuk subjek dengan gaya belajar reflector, $\mathrm{C} 1$ dan $\mathrm{C} 2$ untuk subjek dengan gaya belajar pragmatis dan D1 dan D2 untuk subjek dengan gaya belajar teoritis.

Subjek dengan gaya belajar aktivis (A1) menunjukkan bahwa siswa sudah mampu mencapai indicator dari kemampuan pemecahan masalah yaitu memahami masalah , mampu melakukan perencanaan penyelesaian, melaksanakan rencana dan memeriksa kembali, untuk subjek (A2) secara umum sudah dapat mencapai indicator memahami masalah, menyusun rencana dan melakukan rencana penyelesaian namun belum sepenuhnya tepat dalam memeriksa kembali, hal ini dikarenakan A2 terlalu cepat dan tergesa serta ketidak telitian dalam menyimpulkan atau memeriksa kembali sehingga kurang akurat.

Hal ini sesuai dengan pendapat Perni (2018) yang menyebutkan siswa dengan gaya belajar aktivis dalam melakukan suatu tindakan sering kali kurang pertimbangan secara matang dan lebih banyak didorong oleh kesenangannya melibatkan diri.

Subjek dengan gaya belajar reflector (B1 dan B2) menunjukkan sudah mampu menuliskan apa yang diketahui dan ditanyakan dengan baik, mampu menyusun rencana, namun sedikit salah tetapi pada indicator ketiga yaitu melakukan rencana penyelesaian siswa dengan gaya reflector ini (B1) terdapat sedikit kesalahan yaitu kurang cermat dalam penulisan konstanta di salah satu persamaan, sehingga hal ini mempengaruhi hasil akhir yang diperoleh. Berdsarkan wawancara diketahui hal ini disebabkan karena siswa terburu-buru karena waktu pengerjaan, sehingga tidak teliti melihat informasi yang terdapat pada soal. Hal tersebut sejalan dengan pendapat Zakirman (2017:5) yang menyatakan kelompok siswa yang bergaya reflector tidak mampu bekerja terburu-buru .

Meskipun demikian berdasarkan analisis keseluruhan dapat diketahui kemampuan pemecahan masalah siswa bergaya reflector sudah baik karena walaupun siswa dengan bergaya reflector tidak dapat bekerja dibawah tekanan namun siswa degan gaya belajar ini memiliki kemampuan observasi yang tinggi sehingga membantu siswa dalam menyelesaikan masalah

Subjek dengan gaya belajar pragmatis (C1 dan C2) dalam langkah memahami masalah sudah mampu menyebutkan dan menjelaskan apa yang dimaksudkan dalam soal baik nomor 1 dan 2, namun tidak mampu menyatakan permasalahan dalam bentuk atau model matematika. Karena siswa mengalami kebingungan saat mebuat model 
matematika atau persamaan dari permasalahan yang dimaksud, begitu pula dengan indicator merencanakan penyelesaian dan melakukan rencana penyelesaian siswa dengan gaya pragmatis ini hanya mampu menjawab untuk salah satu dari 2 soal yang diberikan selebihnya belum dapat merencanakan penyelesaian denga tepat, sehingga untuk indicator memeriksa kembali juga belum tepat.

Sehingga siswa bergaya belajar pragmatis dapat dikatakan kurang cermat atau belum mapu dalam merencanakan dan melakukan penyelesaian dalam menggunakan konsep SPLTV dalam penyelesaian masalah. Berdasarkan pembahasan tersebut dapat dikatakan bahwa siswa dengan gaya belajar pragmatis memiliki kemampuan pemecahan masalah yang kurang, terutama dalam merencanakan penyelesaian, dan melakukan rencana penyelesaian. Hal ini karena menurut Sanjaya, dkk (2018:67) siswa dengan gaya belajar pragmatis lebih senang belajar secara praktis dan menyelesaikan maslah dengan menggnkan ide-ide yang praktis pula.

Subjek dengan gaya belajar Teoritis (D1 dan D2) sudah mampu menyebutkan apa yang diketahui dan ditanyakan dari soal nomor 1 dan 2, untuk indicator merencanakan penyelesaian masalah siswa bergaya belajar teoritis sudah mampu menjelaskan dengan baik langkah atau rumus yang akan digunakan untuk menyelesaiakan soal nomor 1 namun sedikit kurang lengakap untuk soal nomor 2, utuk indicator melaksanakan rencana penyelesaian menunjukkan siswa bergaya belajar teoritis mampu melaksanakan rencana penyelesaian dengan baik di 2 soal, tetapi pada indicator keempat yaitu memriksa atau menyimpulkan kembali terdapat salah satu subjek (D1) mengalami sedikit kekeliruan dalam meyimpulkan dengan bentuk kalimat sendiri. Secara umum dapat terlihat bahwa siswa dengan gaya belajar teoritis dapat memenuhi semua indicator kemampuan pemecahan masalah.

Namun siswa dengan gaya belajar teoritis ini memerlukan waktu yang cukup lama dalam belajar karena siswa cenderung memahami teori terlebih dahulu sebelum melakukan praktek. Hal ini sejalan dengan pernyataan Arum (2016: 552) yang menyebutkan siswa bergaya belajar teoritis dalam pembelajaran harus memahami teori terlebih dahulu sebelum melakukan suatu tindakan atau mengambil keputusan.

\section{PENUTUP}

\section{Simpulan}

Kesimpulan yang diperoleh dari pembahasan terkait gaya belajar terhadap kemampuan pemecahan masalah sebagai berikut: 1) Siswa yang memiliki gaya belajar aktivis memiliki kecendrungan senang dengan pengalaman atau permasalahan baru, siswa dengan tipe gaya belajar ini mampu memahami masalah, merencanakan masalah, merencanakan penyelesaian, melaksanakan penyelesaian namun sedikit tergesa-gesa dalam memerikasa kembali. 2) siswa degan gaya belajar reflektor memiliki kemampuan observasi yang tinggi mel sehingga membantu siswa dalam 
menyelesaikan masalah namun masih melakukan kesalahndalam penulisan kalimat matematika terlebih lagi jika bekerja di bawah tekanan. 3) siswa yang memiliki gaya belajar pragmatis memiliki kecendrungan menyukai cara-cara praktis dalam belajar, siswa dengan gaya belajar ini mengalami kesulitan saat merencanakan penyelesaian dan belum dapat dengan sempurna dalam menggunakan konsep SPLTV dalam penyelesaian kalimat. 4) Siswa yang memiliki gaya belajar teoritis memiliki kemampuan pemecahan yang baik . tetapi dapat dikatakan memiliki kemampuan pemecahan maslah yang kurang sebab siswa dengan gaya belajar teoritis ini memerlukan waktu yang cukup lama untuk memahami teori sebelum mengerjakan soal.

Secar umum dapat disimpulkan bahwa setiap siswa dengan gaya belajar berbeda memiliki kemampuan pemahaman konsep yang berbeda-beda pula

\section{Saran}

Saran untuk pendidik hendak nya mengetahui gaya belajar yang dimilki oleh masing-masing siswa, sehinga dpaat mengoptimalkan kemampuan yang ada pada siswa dalam proses pembelajaran khususnya pada pembelajaran matematika.

Sedangkan untuk memfasilitasi kemampuan siswa, pendidik juga dapat memberikan soal-soal lain yang bervariasi dan tidak rutin agar siswa terbiasa dengan menyelsaikan soal-soal yang membutuhkan kemamuan berpikir tingkat tinggi (pemecahan masalah) yang lebih daripada sebelumnya.

Untuk peneliti selanjutnya, diharapkan dapat melakukan penelitian yang serupa namun dengan mengukur kemampuan kemampuan lainnya yang ada di dalam pembelajaran matematika. Sehngga penelitian ini dapat dijadikan referensi dalam melaukkan penelitian lainnya yang lebih mendalam.

\section{DAFTAR PUSTAKA}

Arum,S.Z.P.,\& Khabibah, S. 2016. Profil Pemecahan Masalah Matematika Sisswa SMMA ditinjau dari Gaya Belajar Honey Mumford. Jurnal IImiah Pendidikan Matematika. 3(5): 549-550

Dahar, R.W. 2011. Teori-Teori Belajar \& Pembelajaran. Jakarta: Erlangga

Handoko , Z.P.,\& Wrastati,A.T. 2014. Hubungan Gaya Belajar dengan Metode Pengajaran Guru SMA di Kawasan Surabaya. Jurnal Psikologis Klinis dan Mental. 3(2): 90-96

Heryani,Y.,\& Ramadani.R. 2019. Analisis kemampun pemecahan Masalah Matematis Peserta Didik Berdasarkan 
Gaya belajar. Jurnal Metaedukasi. 1(2): 66-71

Mariam,S., Nurmala,N., Nurdianti, D., Rustyani,N., Desi,A.,A Hidayat,W. 2019. Analisis Kemapuan Pemecahan Masalah Matematis Siswa MTsN dengan Menggunakan Metode Opend Ended di Bandung Barat. Jurnal Pendidikan Matematika. 3(1): 178-186

Palapasari,R., \& Angga, M. 2019. Pengaruh Penerapan Konstruktivitas Realistik dan Kemampuan Dasar matematika Terhadap Peningkatan Kemampuan Pemecahan Masalah Siswa SMP. Jurnal Pendidikan Matematika. 8 (1): 45-56

Perni,N.N. 2018. Penerapan Teori Belajar Humanistik dalam Pembelajaran. Jurnal Pendidikan Dasar. 3 (1)

Rosmawati, Elniati., S. Murni, D. 2012. Kemampuan Pemecahan Masalah dan Lembar Kegiatan Siswa Berbasis Problem Solving. Jurnal Pendidikan Matematika 1 (1): 80-84

Sanjaya, I.I, Maharani, H.R.,\& Basir,M.A. 2018. Kemampuan Representasi Matematis siswa pada Materi Lingkaran Berdasarkan gaya Belajar Honey Mumford. Jurnal Penelitian Didaktik Matematika. 292): 60-72
Sugiyono. (2014). Cara Mudah Menyusun Skripsi, Tesis dan Disertasi. Bandung : CVAlfabeta.

Sugiyono. (2015). Metdoe Penelitian Kuantitatif, Kualitatif dan R\&D. Bandung : CV Alfabeta.

Zakirman. 2017. Pengelompokan Gaya Belajar Mahasiswa menurut Teori Honey Mumford Dalam

Paradigma Perpustakaan. Jurnal Perpustakaan, Arsip dan Dokumen. 8(2):133-142 